\title{
Competition and Stability in the credit industry: banking vs. factoring industries
}

\author{
Marta Degl'Innocenti ${ }^{\#}$ \\ Southampton Business School, UK \\ Franco Fiordelisi ${ }^{\dagger}$ \\ University of Rome III, Italy \& Middlesex University in London, UK. \\ Irwan Trinugroho ${ }^{\#}$ \\ Universitas Sebelas Maret, Indonesia
}

\begin{abstract}
Over the last decade, most credit-industries registered a decline in lending volumes, while factoring industries instead registered a substantial growth in terms of turnover. Surprisingly, only a handful of papers so far investigate factoring companies. Do factoring firms display the same stability levels of banks? Is the competition similar in factoring and banking industries? Is the relationship between competition and stability the same in these industries? Focusing on Italy (one of the largest factoring and banking markets in Europe) and using a unique dataset, we show three main results: factoring companies are (on average) more stable than banks; 2) the stability of factoring companies increase when competition declines (competition-fragility view); 3 ) the competition-fragility view is weaker in the factoring industry than in the banking industry. Our findings indicate that competition in the Italian credit industry was greater in factoring than in banking.
\end{abstract}

JEL classification: G21, G23, G28

Keywords: Banking, Factoring, Competition, and Stability

Acknowledgement: We would like to thank, Vincenzo D'Apice, Pierpaolo Ferrari, Ornella Ricci, Giovanni Cerulli, and the collaboration of the Italian Banking Association(ABI), the Italian Factoring Association (Assifact). We also thankful to SDA Bocconi in Milan for providing us data from the "Osservatorio sugli Intermediari Finanziari Non Bancari" (OSSFIN).

\footnotetext{
\# Southampton Business School, Highfield, Southampton, SO17 1BJ, United Kingdom. Tel. +44 2380598093 , Email address: m.deglinnocenti@soton.ac.uk

$\dagger$ School of Economics and Business, Via S. D’Amico 77, 0045 Rome, Italy; (39) 06 57335672; email: franco.fiordelisi@uniroma3.it

${ }^{\#}$ Faculty of Economics and Business, $1^{\text {st }}$ Building, Jalan Ir. Sutami 36 A, Surakarta, Central Java, Indonesia
} 


\section{Introduction}

In the last decade, most credit-industries registered a decline in lending volumes, while factoring industries instead registered a substantial increase in terms of volume. Since the Global Financial Crisis of 2008, many firms, particularly SMEs, experienced greater difficulty in obtaining traditional bank funding. Conversely, the financial crisis increased companies' demand for tradecredits, and this explained the increase for factoring services. In particular, the total factoring volume in EU increased by $62 \%$ (from $€ 990$ to $€ 1,606$ in billions) over the period $2010-2017$. Factoring provides a mix of financial services $^{1}$ including credit protection, receivable management, and collections. It has now become a primary source of funding for most firms in Europe (the factoring and commercial finance was 10.4\% of European GDP in 2016). Like banks, factoring companies are supervised in most European countries and it is critical for supervised authorities to understand if a greater competition in the industry would lead factoring companies to increase their risk-taking (e.g. financing riskier borrowers to increase their market power) or decrease their risk taking (e.g. becoming more selective in screening borrowers to minimize credit losses). The good functioning of the factoring industry is important to provide greater financing flows to companies.

The competition-stability nexus has gathered a lot of attention in the banking literature (Goddard and Wilson, 2009; Wilson et al., 2010). Surprisingly however, past papers have essentially focused on the banking industry, omitting to consider other sectors within the credit industries. This is mostly due to the lack of data in non-banking financial institutions. This paper covers this gap and provides new findings on the relationship between competition and stability in the factoring industry. The main contribution of our study to the existing literature dealing with

\footnotetext{
${ }^{1}$ See Fiordelisi and Molyneux, (2004) for more details on the factoring industry.
} 
the link between competition and stability is that, as far as we are aware, this denotes the first attempt at investigating this issue in a non-banking credit sector, such as the factoring industry.

Specifically, we test our hypotheses by jointly analysing banking and factoring firms and controlling for bank characteristics and macroeconomic determinants. Firm stability is estimated using two variables: the Z-score and the Capital at Risk (CAR). Competition is estimated using the Lerner Index which is employed extensively in the existing banking literature (Carbò et al., 2009; Cipollini and Fiordelisi, 2012; Liu and Wilson, 2013, Liu et al., 2013; Fiordelisi and Mare, 2014, Degl'Innocenti et al., 2018, 2019; Clark et al., 2018, Fiordelisi, Mare, and Molyneux 2018). We use a panel-data vector auto-regression to examine the link between competition and bank risk measures.

Furthermore, we make use of a unique dataset of Italian factoring companies ("Osservatorio sugli Intermediari Finanziari Non Bancari (OSSFIN) database). Our focus is on Italy for various reasons. First, credit institutions are major players in the Italian financial systems and, of course, banks are the most important credit institutions. However, factoring companies have grown consistently during the last decade and the Italian factoring industry is one of the major factoring markets in Europe with a total turnover of 209 Euro billions, i.e. $13.9 \%$ of the whole European market and $12.5 \%$ of the Italian $\mathrm{GDP}^{2}$. Second, factoring companies are supervised as specialized financial intermediaries and the link between competition and stability (both are aims of the supervisory authority) is crucial both in banking (where there is extensive evidence) and the factoring industry.

\footnotetext{
${ }^{2}$ Source of data: EU Federation website: https://euf.eu.com/total-factoring.html.
} 
We find four main results. First, we show a positive link between firm market-power and stability in the credit industry (both factoring and banking) supporting the competition fragilityview. Second, factoring companies are (on average) more stable than banks in the Italian credit industry. Third, we show that the competition-fragility view is weaker in the factoring industry than in banking. Fourth, the impulse responses of risk variables to variation in competition degree, and vice versa, mainly show significant patterns for the factoring industry. Particularly, we find a significant and negative response of the Z-score and the CAR in the short run to possible shocks in the Lerner Index, but such an effect tends towards zero in the medium term. Finally, we find evidence that the Lerner Index decreases as the effect of a shock in the Z-score, while increases because of a shock in the CAR in the factoring industry.

Our paper provides new important insights to policy makers, practitioners, and academics that there are differences between factoring firms and banks in terms of stability (greater in factoring), competition (greater in factoring), and in their relationship (where the competitionfragility view is weaker in factoring). Overall the factoring industry appears to be more stable than commercial banks and less vulnerable to financial crises because of the peculiarity of its business model. However, policy makers should be aware of the fact that the level of stability of the sector could decrease as the effect of the consolidation process and a consequent increase of the factoring firms' market share. Furthermore, the creation of a niche of specialization in terms of industrial and geographic markets could further enhance the monopoly market power of certain financial intermediaries in the factoring industry in this way harming both the competition and the stability of the financial industry. In spite of the idiosyncrasies of the factoring business, commercial banks could still look at the practices adopted in the factoring industry to advance risk management (and potentially decrease non-performing loans). 
The paper is organized as follows. Section 2 provides an overview of the factoring industry in Italy. Section 3 discusses the literature review and the hypotheses; Section 4 presents the methodology (Section 4.1.) and the estimation procedure for the competition measures (Section 4.2) and stability (Section 4.3). Sections 5 presents the data. Section 6 reports the summary statistics and preliminary investigation, while Section 7 describes the empirical findings. Finally, Section 8 concludes.

\section{An overview of the factoring industry in Italy ${ }^{3}$}

Since the 2008 financial crisis, the Italian factoring industry has seen a strong increase of almost $72.3 \%$ in terms of turnover. Furthermore, the relevance of the total turnover for factoring in Italy is almost $13 \%$ of the GDP and it has seen an increase of almost of $23 \%$ over the period 2011-2016. Nowadays, factoring represents one of the major sources of firms to finance their working capital especially for firms operating in the manufacturing, service, and retail sectors in Europe.

Factoring services can be offered by bank-related, independent, captive firms or banks. Commercial banks tend to create an ad-hoc firm within the group that deals with factoring services/products (e.g. UBI factor, Unicredit Factoring). Financial intermediaries that belong to a banking group cover almost $50 \%$ of the entire market in terms of turnover. Captive firms refer instead to firms that have been created by industrial groups to offer factoring products/services (e.g. GE capital), while independent firms do not do belong to any group. Captive and independent

\footnotetext{
${ }^{3}$ The source for the data reported in this section is Assifact, the Italian association of factoring.
} 
firms deal with more than $10 \%$ of the total factoring turnover in Italy, while the remaining market share belongs to banks.

In Italy, factoring firms are financial intermediaries subject to equivalent regulatory requirements of the banking sector (for example in terms of capital reserves and loan loss provisioning) based on the principle of proportionality. Instead, due to the characteristics of the business, factoring firms do not usually hold off-balance sheet activities. Furthermore, differently from banks, factoring firms cannot collect deposits.

$$
<\text { Insert Table } 1>
$$

\section{Literature review and research hypotheses development}

The banking literature has already thoroughly examined the link between competition and stability (Goddard and Wilson, 2009; Wilson et al., 2010). Higher competition is often related to more innovation (Cornaggia et al., 2015), greater efficiency (Casu and Girardone, 2009, Schaeck and Cihák, 2014), higher quality products and better prices for customers (Anginer et al., 2012), or it entails holding more capital (Beck et al., 2006; Schaeck et al., 2009). The economic conditions at the regional level play a pivotal role in affecting the stability of European banks (Liu et al., 2013). Moreover, from a social welfare perspective, greater competition contributes to decrease the deadweight loss generated by market power via lower spreads (i.e., Harberger's triangle - lower output and higher price) (Chortareas et al., 2012). However, competition can also harm the "charter value" of banks, in this way increasing the instability of the financial system (Allen and Gale, 2004). Maximum welfare may engender negative externalities if it lowers bank stability. Indeed, regulation is justified by the presence of important barriers to entry that prevent proper contestability in banking triggering a more pervasive role for supervisors. Regulation is a particularly intricate determinant to assess as it can for instance a) soften competition by rising 
barriers to entry, b) restrict banking activities, and c) alter the competitive position of banks via prudential rules (Degryse and Ongena, 2007).

The theoretical concerns hinges on the link between competition and stability (Keeley, 1990; Allen and Gale, 2004; Boyd and De Nicolò, 2005). Several studies try to assess the extent of this trade-off. For example, Anginer et al. (2012) show that competition can increase stability at the systemic level. Other scholars, (e.g. Boyd et al. (2006) and De Nicolò and Loukoianova (2007)) point out that financial instability can increase in systems with low competition. In contrast, Beck et al. (2006) argue that more concentrated banking markets exhibit a lower likelihood of incurring systemic crises and might be more resilient than competitive markets. This is reasonable as, for instance, a well-organised cartel could be more effective in increasing stability than a large number of small competing banks or few larger institutions, which can be easier to monitor (Allen and Gale, 2000). Yet if so, this could involve a welfare cost. Cross-country empirical findings on the causality between competition, concentration and risk is mixed. Focusing on 45 countries over the period 1980-2005, Schaeck et al. (2009) show that more competitive and less concentrated banking markets are less likely to incur a systemic crisis. Fu et al. (2014), focusing on the Asia Pacific countries, postulate that concentration increases bank instability and that lower market power induces higher financial fragility. Focusing on 23 developed countries, Berger et al. (2009) show that bank market power can enhance riskier portfolios. However, they also find that the decrease of stability can be counterbalanced by a greater franchise value. Some recent papers employ multifarious factors able to explain the dynamics of the relationship such as regulation, institutional elements, and the economic environment. So far, a few papers have investigated the role of systemic risk and related the cost of government intervention to market power. Fiordelisi and Mare (2014) analyse European cooperative banks and find that the financial 
crisis of 2007 does not affect the negative link between market power and bank stability. Soedarmono and Tarazi (2015) advocate that the financial crisis has modified market competitiveness and triggered banking reforms. Therefore, we posit that market power can in part shield financial institutions from economic downturns through for instance a margin effect (Martinez-Miera and Repullo, 2010), higher profits, and capital buffers (Allen and Gale, 2004).

Various financial intermediaries are exposed to different sources and degrees of risk. Amongst them, the financial intermediaries specialized in the factoring sector appear to experience less loss rates compared to banks dealing with traditional banking credit in Europe ${ }^{4}$. In Italy, the percentage of non-performing loans on bank loans was above $10 \%$ in 2016 while it barely reached the $4-5 \%$ in the case of the factoring industry ${ }^{5}$. This difference of performance between these financial intermediaries can be traced to the peculiarities of the factoring sector since the funding is made against the trade receivables of the user business. Furthermore, the credit risk is distributed amongst the business' debtors. This makes this form of funding less risky and accessible for small and less established firms. In addition, within Europe, the factoring sector is dominated by a variety of players (mainly represented by banks and bank-related financial intermediaries), which can be specialized on various industrial and geographical markets. This can affect the way these financial intermediaries compete with each other.

We therefore formulate the following questions: is the competition and stability of factoring companies similar to banks? Is the relationship between competition and stability the same in the banking and factoring industries? And does a greater level of competition increase

\footnotetext{
${ }^{4}$ Source: EUF (2015).

${ }^{5}$ Source: Assifact (2018).
} 
risk-taking in the factoring industry (the competition-fragility view ${ }^{6}$ ) or does it reduce risk-taking (the competition-stability view ${ }^{7}$ )? We investigate whether factoring firms and commercial banks are exposed to the same competition-stability relationship. This could be relevant to understand the mechanisms underlying stability in a heterogeneous financial ecosystem characterized by various financial players more or less specialized in a particular product or service. The next section explains the data and the empirical strategy that we employ to address our research questions.

\section{Methodology and description of the variables}

\subsection{The link between risk and competition}

To assess the risk-competition link, we employ a panel-data vector auto-regression approach $(\mathrm{PVAR})^{8}$ that accounts for endogeneity concerns because of the reverse causality between risk and competition and allows for an examination of the impulse responses of risk measures to variations in the degree of competition (and vice versa). In particular, our baseline model is as follows ${ }^{9}$ :

$Y_{i t}=Y_{i t-1} A_{1}+X_{i t} B+u_{i}+e_{i t}$

where $\mathrm{Y}_{(\mathrm{t})}$ includes risk and competition measures. Both risk and competition measures are considered as endogeneous variables. $X_{i t}$ consists of a vector of exogenous covariates, and $B$ is

\footnotetext{
${ }^{6}$ Allen and Gale (2004); Forssbæck and Shehzad (2015)

${ }^{7}$ Boyd and De Nicolò, (2005); De Nicolò and Lucchetta, (2009)

${ }^{8}$ For our analysis we use the Stata program developed by Abrigo and Love (2016).

${ }^{9}$ For recent applications of the model proposed by Love and Zicchino (2006) and Abrigo and Love (2016) see e.g. Degl'Innocenti et al. (2018, 2019), Delis et al., (2014), Head et al., (2014).
} 
the matrix of the parameters to be estimated. Finally, $u_{i}$ is the vectors of dependent variablespecific panel fixed-effects. Finally, $e_{i t}$ indicates idiosyncratic errors.

To reduce endogeneity issues due to omitted variables, we have time-demeaned the original variables. In addition, we have removed fixed individual effects. Next, we employ the GMM estimator of the model transformed by the forward orthogonal deviation that appear to perform better than the first difference (Hayakawa, 2009). For our analysis, we use traditional instruments, as our period is relatively short. As pointed out by Hayakawa (2016, 2019), conventional estimators using instruments in levels have comparable sample properties to the new instruments in a univariate $\mathrm{AR}(\mathrm{p})$ when $\mathrm{T}$ is small.

Additionally, we run panel unit-root tests and we found no unit roots in the endogenous variables. Concerning this, as stressed by Abrigo and Love (2016), the GMM estimator can suffer from weak instrument issues if the endogenous variables exhibit a unit root. Next, we employ the procedure proposed by Andrews and Lu (2001) for GMM models. This allows us to choose the number of lags to include in the model based on Hansen's (1982) J statistic of over-identifying restrictions. The test indicates that one lag is optimal. As suggested by Hayakawa (2016), we employ generalized IRFs that do not depend on the ordering of variables as orthogonalized IRFs do. Then, we generate bootstrapped confidence intervals to get the impulse response functions by running 1,000 Monte Carlo simulations.

Finally, we present the forecast-error variance decomposition (FEVD). This allows us to assess the percentage of change in risk (competition) explained by the 'shock' to competition (risk) over time. FEVD is calculated following the Cholesky decomposition of the residual covariance 
matrix obtained with the panel VAR approach. As suggested by Abrigo and Love (2016), we do not consider the exogenous variables when computing FEDV.

The set of covariates, $X_{i t}$, includes market share and performance. The latter one is calculated by using the return on assets, ROA. On the one hand, banks with a high market share or performance can wield a greater market power because of cost advantages and the capability to set higher prices (e.g. Fernandex De Guevera et al., 2005, Carbò et al., 2009; Clark et al., 2018). On the other hand, financial institutions with high market share and size in the market could also undertake risk-taking behaviour under the perception that big banks will be bailed-out if they find themselves in a distressed situation (e.g. Dam and Koetter, 2012; Hakenes \& Schnabel, 2010).

\subsection{Measuring industry competition}

In order to measure market conditions in the banking and factoring industries, we employ both non-structural and structural indicators of competition. Specifically, we use a structural indicator of competition, i.e. the market share of each firm computed based on total assets. Differently from the Herfindahl-Hirschman Index (HHI), the market share allows us to investigate the competitive dynamics of each firm.

We also use a non-structural indicator capturing competition at the bank individual level. Particularly, we use the Lerner index of monopoly power $(L E R)$, that has been largely adopted in past studies analysing competition in banking (recently, Turk-Ariss, 2010; Fiordelisi and Mare, 2014 Forssbæck and Shehzad, 2014; Degl'Innocenti et al., 2018, 2019; Clark et al., 2018).

The Lerner index indicates a firm's capability to fix prices above its marginal production cost

$\left.\left(\operatorname{LER}=\left(P_{i t}-M C_{i t}\right) / P_{i t}\right)\right)$, where $P$ is the average selling price and $M C$ is the marginal cost of 
production. For both factoring companies and banks, we define one single output, $Y_{i t}$ capturing the whole activity of the firm that is total earning assets. The output price, $P_{i t}$, is approximated by the ratio between total interest revenues and turnover in the case of factoring companies, and by the ratio between total revenue and total assets in the case of banks.

The estimation of the marginal cost needs the definition of the cost function for firms competing in the industry. Two very important issues have been addressed here: the definition of inputs and outputs in the banking and factoring industries; and the form of the cost function in the industry. Regarding the first issue, we define a single output $\left(Y_{i t}\right)$ for both factoring companies and banks (the total earning assets for banks) and three inputs for both factoring companies and banks. For both types of financial companies, these are measured in the same way: human capital $\left(X_{1 i t}\right)$ measured by the total staff expenses); physical capital $\left(X_{2 i t}\right)$ measured by the total value of tangible assets); and financial capital $\left(X_{3 i t}\right)$ proxied by the total liabilities. Consequently, we define the input prices as follows: human capital price $\left(W_{1 i t}\right)$ is obtained as the total personnel expenses and total assets; physical capital price $\left(W_{2 i t}\right)$ is calculated as the ratio of other operating expenses and other administrative expenses to total fixed assets; and financial capital price $\left(W_{3 i t}\right)$ is calculated as the total interest expenses over total liabilities. Regarding the second issue, we define a translog cost function (consistently with past papers, as Lu and Wilson, 2013; Fiordelisi and Mare, 2014; Forssbæck and Shehzad, 2015; Clark et al., 2018; Degl'Innocenti et al., 2019) ${ }^{10}$, for each industry as follows:

\footnotetext{
${ }^{10}$ We run stochastic cost frontier model for panel data.
} 


$$
\begin{aligned}
\ln \left(T C_{i t}\right) & =\beta_{0}+\beta_{1} \ln Y_{i t}+\sum_{h=1}^{3} \beta_{h} \ln W_{h i t}+\frac{1}{2} \beta_{Y Y}\left(\ln Y_{i t}\right)^{2}+\frac{1}{2} \sum_{h=1}^{3} \sum_{m=1}^{3} \beta_{h m} \ln W_{h i t} \ln W_{m i t}+ \\
& +\sum_{h=1}^{3} \beta_{Y h} \ln Y_{i t} \ln W_{h i t}+\tau_{1} T+u_{i t}+v_{i t}
\end{aligned}
$$

$$
\text { for }(h \neq m)
$$

where TC denotes total cost (including personnel and administrative expenses, and interest expenses), $W_{h j \mathrm{t}}$ are the input factors of the cost function defined for factoring companies and banks. Marginal costs can be calculated from equation (1) by considering the derivative relating to the single output $\left(\mathrm{Y}_{1 i t}\right)$, which yields:

$$
M C_{i t}=\frac{T C_{i t}}{Y_{i t}}\left[\beta_{1}+\beta_{Y Y} \ln Y_{i t}+\sum_{h=1}^{3} \beta_{Y h} \ln W_{h i t}\right]
$$

Since banking and factoring industries have different features (e.g. banks have a distribution system based on a large number of branches and offer a wide range of financial services; factoring companies have typically few branches and focus on trade credit), we cannot safely control for all differences estimating a common cost function. As such, we estimate a specific cost function for each of the two industries.

\subsection{Measuring industry stability}

We use two main risk measures for our analysis. Specifically, we calculate the banks' CapitalAt-Risk (CAR) that indicates how much capital a firm or bank would need to offset the risks that it is facing as a running concern. For the scope of the paper, we calculate the Earning at Risk (EAR), which is the worst change in earnings that a bank or firm is facing over a fixed-time horizon given a fixed confidence level. EAR is a common risk measure in the banking literature (Stein et al., 2001; Andrén et al., 2005). 
EAR is computed as follows:

$$
E A R=\eta+z_{(1-\alpha) / 2} \sigma
$$

where $\eta$ measures the firm or bank's profit before tax (PBT); $\sigma$ indicates the standard deviation of $P B T$; and $z_{(1-\alpha) / 2}$ is the probability related to the $\alpha$ confidence level. In this case, we assume that earnings follow a normal distribution. Specifically, CAR then indicates the amount of equity equivalent to the current value of perpetuity of EAR that a firm needs to keep under the expectation that earnings will decrease permanently or over a longer term. The formula presents the following form:

$C A R=E A R / R O E$

where $R O E$ indicates the mean value of return on equity. A higher value of CAR suggests a higher risk for a firm or bank. Secondly, we introduce a bank stability measure that is the Z-score. This measure has been widely employed in the banking literature (e.g. Laeven and Levine, 2009; Radic et al., 2012; Danisewicz et al., 2017). This measure is constructed as the ratio of the return on assets (ROA) plus the capital at risk (CAR) divided by the standard deviation of ROA ( $\sigma$ ROA). Consistently with Hesse and Cihák (2007), we calculate a time varying indicator of bank stability. Specifically, $\sigma R O A_{t}$ is computed employing a cross-sectional approach and combining this with $\mathrm{CAR}_{t}$ and $\mathrm{ROA}_{t}$ at time $\mathrm{t}$ for each firm/bank. Higher values of Z-score indicate higher degree of solvency and bank soundness. We take the log of the Z-score.

\section{Data}

The lack of past studies dealing with non-banking credit companies is mainly due to the lack of data. For the Italian factoring industry data was obtained by collecting the financial reports of 
supervised factoring companies in Italy from the OSSFIN. There are no public source of information or data for factoring firms. On the contrary, there are various sources of data for banks. Specifically, we obtained data for 75 commercial banks over the period 2008-2015 from Fitch-IBCA BankScope (BSC). Overall, our sample includes both factoring and banking companies: we collected data for 33 factoring companies over the period 2008-2015 (707 firmyear observations). The number of observations is reported in Table 2 .

$<$ Insert Table $2>$

We also summarize the definition and calculation procedure of our main variables in Table

3.

$<$ Insert Table $3>$

\section{Summary statistics and preliminary investigation}

In this section, we report the summary statistics of the variables included in the model (Table 4). We observe a high variability among the firms included in the dataset in terms of size, Z-score and CAR.

By looking at the industry competition, the Lerner Index (and the variables related to the inputs and outputs used to run the cost translog function) shows a similar mean level of competition in banking and factoring industries (i.e. 0.488 and 0.409 , respectively). The magnitude of the Lerner index is quite modest suggesting that the competition is high in both industries. The lower level of market power in the factoring sector is driven by low prices. Specifically, the mean ratio of interest rates over the turnover (total flow of traded credit) declined by $0.59 \%$ in 2012 to $0.36 \%$ in 2016 and, similarly, the mean ratio of interest rates over the mean loan (i.e. annualized flow of traded credit) declined by $3.28 \%$ in 2012 to $2.06 \%$ in 2016 . 
$<$ Insert Table $4>$

Next, we report a preliminary investigation by comparing our stability and competition measures in the factoring and banking industries. Specifically, Figure 1 indicates the change of competition indicators in the factoring and banking industry. What emerges is that the competition level of the factoring market between 2008 and 2009 is higher than the one in the banking industry (Figure 1c). Specifically, the HHI evolution between 2008 and 2015 show both a substantially lower concentration (Figure 1a vs. 1c) in the factoring industry than in banking, and a lower market power (Figure $1 \mathrm{~b}$ and $1 \mathrm{~d})$. Interestingly, we observe that the concentration has slightly increased in the factoring industry between 2008 and 2015, but this is not associated with a greater market power of factoring firms. Conversely, we note the slight decline in the banking sector, which is related to a market power increase (between 2010 and 2014). Both for factoring and banking companies, we note a decline in market power in $2015(\mathrm{t}=8)$.

\section{$<$ Insert Figure 1 $>$}

To have a first statistical test of differences between banks and factoring companies, we run a two-sample t-test with equal variance between the Lerner Index (Table 5). The results shows that the market power (Lerner Index) of factoring firms, on average equal to 0.403 , is statistically and significantly lower than that of commercial banks, which on average is equal to 0.484 . This is further evidence that competition in the Italian credit industry was greater in factoring than in banking.

$<$ Insert Table 5> 


\section{Results}

\subsection{Main Results}

We employ a panel fixed effect model to assess the effect of competition on risk measures, Zscore, and CAR. To start, we estimate the joint impact of the Lerner Index and the type of credit institution (factoring vs banking) on firm stability (Z-score). Specifically, we have created a dummy (labelled Factoring), which is equal to 1 for factoring firms, and zero otherwise (banks). Therefore, we can distinguish between factoring firms and commercial banks and to better control for intra-industry competition dynamics. We also include firm fixed effects and time*type of firm (i.e. year * Factoring dummy) to control for events that could have affected each company, and the industry in a different way over time.

Table 6 reports the main results. Specifically, we find the factoring dummy has a positive and significant coefficient with respect to firm stability. This means that factoring companies are (on average) more stable than banks. Second, we observe a positive and statistically significant link between market power and firm stability (both for the Lerner index and firm market share). These results support the competition fragility-view as firm stability increases when firm market power increases (and so competition declines) as well. Interestingly, we find that the interaction between the factoring dummy and our measures of market power is negatively and statistically significant. This suggests that the competition-fragility view is weaker in the factoring industry than in the banking sector. Finally, our findings show a negative link between size and firm stability. This suggests that firm stability declines (on average) as firm asset size increases.

As a robustness check, we also measure firm stability focusing on the CAR (columns 2 and 3). Results are strongly consistent, except for the link between the CAR and the interaction between 
market share and factoring. Specifically, Market Share*Factoring impacts negatively on stability and positively on capital at risk; this would suggest that a consolidation process of the factoring firms with a consequent increase of the market share may increase their risk.

$<$ Insert Table 6>

\subsection{Impulse responses}

In this section, we calculate the orthogonalised impulse responses of the banks' risk (competition) to competition (risk) shocks. Figure 2 shows the results for factoring firms, while Figure 3 shows the same or commercial banks. Figure 2a shows the change $(\Delta)$ in the Z-score because of a shock to the Lerner Index. Instead Figure $2 \mathrm{~b}$ presents the results relative to change $\Delta$ in the CAR as a result of a shock to the Lerner Index. The solid lines show the response of these variables. Instead the grey area represents the $95 \%$ confidence interval. We consider three periods for the simulation horizon.

\section{$<$ Insert Figure 2>}

Furthermore, we notice a significant and negative response of the Z-score to one standard deviation shock in the Lerner Index (Figure 2a). Specifically, one standard deviation shock to the Lerner Index will decrease the Z-score visibly in the first period. However, such an effect appears to tend towards zero in the medium term. We show a similar pattern for the CAR. However, the size of the response of the CAR to shocks to the Lerner Index appears to be more marginal than the Z-score. The Figure $2 b$ shows that the impulse-responses of the Lerner Index to risk' shock in the case of factoring firms. We note a statistically significant and negative response of the Lerner Index to shocks in the Z-score in the short term. In contrast, we notice that there is a significant and positive effect of the Lerner Index as the consequence of a shock to the CAR in the short and 
medium term (Figure 2b). Particularly, after a slight increasing pattern, the Lerner Index declines again as the effect of a shock in the CAR. Therefore, we can argue that overall the Lerner Index exhibits a positive and significant trend to a one standard deviation shock in the CAR. Finally, we highlight that the confidence interval for the impulse-response function in the case of the CAR is rather large. Specifically, the confidence interval is wider after the first period. Even though we have transformed the data, we still find the existence of a heterogeneity effect in the response function of risk to change in competition. This effect is clearer after a single period of shock.

Figure 3 illustrates the impulse response functions to the impulse-responses of risk to a shock to the Lerner index for commercial banks. Figure 3a reports the impulse-response functions for the Z-score and the CAR to shock to Lerner Index.

$<$ Insert Figure 3>

Differently from factoring firms, we do not find any significant response of the Z-score to one standard deviation change in the Lerner Index (Figure 3a). Instead, the Lerner Index appears now to significantly increase for the effect to shock of the Z-score. However, such an impact is only significant in the short-term. Turning to the CAR-Lerner Index linkage, we did not find any significant effect for any impulse-responses functions (Figure 3b).

Table 7 shows the Variance Decomposition (VDCs) where the forecast horizons consists of three periods. Particularly, regarding the Lerner Index and risk relationship for the factoring industry, Table 7 shows that almost 3\% variation in the Z-score is explained by shocks in the Lerner Index, while $16 \%$ of variation in the Lerner Index is explained by shocks in the Z-score in the factoring industry. Similarly, about $15 \%$ variation in the CAR is explained by shocks in the Lerner Index, while $40-50 \%$ of the variation in the Lerner Index is explained by the CAR for factoring firms (in the $2^{\text {nd }}$ and $3^{\text {rd }}$ period). In contrast, variations in the Lerner Index are not so 
relevant for the change of the Z-score and the CAR of commercial banks and vice versa.

$<$ Insert Table $7>$

\section{Conclusions}

Competition is seen to play a pivotal role in spurring greater efficiency, innovation, and generally in favouring a more efficient allocation of financial resources. However, the recent financial crisis has raised some concerns among scholars and policy makers on its role in stimulating higher bank risk-taking (Degl'Innocenti et al., 2019).

This paper offers new insight on the importance of the relationship between risk and competition for both the factoring and banking industry in Italy. To this end, we make use of a panel data model with firm, time, and industry fixed effects to analyse the relationship between risk and competition. Then, we use a panel VAR to examine the impulse responses of risk variables, Z-score and CAR, to changes in the Lerner Index, and vice versa. Our dataset encompasses 707 observations over 2008-2015.

We obtain three main results. First, factoring companies are (on average) more stable than banks. Second, the stability of factoring companies increases when firm market power increases as well (and so competition declines): this supports the competition fragility view. Third, the competition-fragility view is weaker in the factoring industry than in the banking industry. Overall, our findings indicate that competition in the Italian credit industry was greater in factoring than in banking.

Finally, we run a panel-VAR model to estimate banks' risk measures reaction to competition shocks and vice-versa. We find that factoring firms' response in the Z-score is significantly and negatively related to variation in the Lerner Index only in the short-term impulse responses in the factoring industry. Instead, we show that the Lerner Index decreases as the effect of a shock in the 
Z-score, while increases because of a shock in the CAR. This suggest that competition will increase as the consequence of one standard deviation change in the Z-score or decrease as the consequence of one standard deviation change in the CAR. Finally, we find empirical evidence that competition decreases (the Lerner Index increases) as the effect of one standard deviation shock in the Z-score in the banking industry. In other words, this finding suggests that as a bank increases its stability, it also consolidates its monopoly market power. As a counter effect, this can harm competition in the banking system.

Our paper provides important insights to policy makers, practitioners, and academics with regards to there being differences between factoring firms and banks in terms of stability (greater in factoring), competition (greater in factoring), and in their relationship (where the competitionfragility view is weaker in factoring). Overall, the factoring industry appears to be more stable than commercial banks and less vulnerable to financial crises because of the peculiarity of its business model. However, policy makers should be aware of the fact that the level of stability of the sector could decrease as the effect of the consolidation process and a consequent increase of the factoring firms' market share. Furthermore, the creation of a niche of specialization in terms of industrial and geographic markets (as in the case of the Italian factoring industry) could enhance both the competition and the stability of the financial sector. 


\section{References}

Abrigo, M.R.M., Love, I. (2016). Estimation of Panel Vector Autoregression in Stata: a Package of Programs. Stata Journal 16: 778-804

Allen, F., Gale, D. (2000). Financial Contagion. The Journal of Political Economy 108(1): 1-33.

Allen, F., Gale, D. (2004). Competition and Financial Stability. Journal of Money, Credit, and Banking 36(3): 453-480.

Andrén, N., Jankensgard, H., Oxelheim, L. (2005). Exposure-based cash-flow-at- risk: An alternative to value-at-risk for industrial companies. Journal of Applied Corporate Finance 17(3): 76-87.

Assifact (2018). La valutazione, la misurazione e la gestione del rischio di credito nel factoring. Assifact Education.

Andrews, D.W.K., Lu, B. (2001). Consistent model and moment selection procedures for GMM estimation with application to dynamic panel data models. Journal of Econometrics, 101(1): 123-164.

Anginer D, Demirguc-Kunt A, Zhu M. (2014). How does competition affect bank systemic risk? Journal of Financial Intermediation 23:1-26.

Beck, T., Demirgüç-Kunt, A., Levine, R. (2006). Bank concentration, competition, and crises: First results. Journal of Banking and Finance 30: 1581-603.

Berger, A., L. Klapper, Turk-Ariss, R. (2009). Bank Competition and Financial Stability. Journal of Financial Services Research 35: 99-1.

Boyd, J.H., De Nicolò, G. (2005). The Theory of Bank Risk Taking and Competition Revisited. The Journal of Finance 60 (3): 1329-1343.

Boyd, J.H., De Nicolò, G., Al Jalal, A. (2006). Bank Risk-Taking and Competition Revisited: New Theory and New Evidence. IMF Working Papers 297, International Monetary Fund, Washington. D.C.

Carbó-Valverde, S., Marques-Ibanez, D., Rodríguez-Fernández, F. (2012). Securitization, risktransferring and financial instability: The case of Spain. Journal of International Money and Finance 31: 80-101.

Carbò, S., Humphrey, D., Maudos, J., Molyenux, P. (2009). Cross-country comparisons of competition and pricing power in European banking, Journal of International Money \& Finance 28: 115-134.

Casu, B., Girardone, C., (2009). Testing the relationship between competition and efficiency in banking: A panel data analysis. Economics Letters 105: 134-137.

Chortareas, G.E., Garza-García, J.G., Girardone, C., (2012). Competition, efficiency and interest rate margins in Latin American banking. International Review of Financial Analysis 24: 93-103.

Cipollini, A., Fiordelisi, F. (2012). Economic value, competition and financial distress in the European banking system. Journal of Banking and Finance, 36: 3101-3109. 
Clark, Ephraim A. Davide M., Radić, N. (2018). Cooperative banks: What do we know about competition and risk preferences? Journal of International Financial Markets, Institutions \& Money 52: 90-101.

Cornaggia, J., Mao, Y., Tian, X. \& Wolfe, B. (2015). Does banking competition affect innovation? Journal of Financial Economics 115: 189-209.

Dam, L., and M. Koetter. (2012). Bank Bailouts and Moral Hazard: Empirical Evidence from Germany. Review of Financial Studies 25: 2343-2380.

Danisewicz, P., McGowan, D., Onali, E., Schaeck, K. (2017). Debt Priority Structure, Market Discipline, and Bank Conduct. Review of Financial Studies. Forthcoming. https://doi.org/10.1093/rfs/hhx111.

De Nicoló, G., Loukoianova, E. (2007). Bank Ownership, Market Structure and Risk. International Monetary Fund, Working Paper 02/125.

De Nicolò, G., Lucchetta, M. (2009). Financial Intermediation, Competition, and Risk: A General Equilibrium Exposition. International Monetary Fund, Working Paper 09/105.

Degl'innocenti, M., Mishra, T., \& Wolfe, S. (2018). Branching, lending and competition in Italian banking. European Journal of Finance 24(3): 208-230.

Degl'Innocenti, M., Fiordelisi, F., Girardone, C., Radić, N. (2019) Competition and risk-taking in investment banking. Financial Markets, Institutions \& Instruments. Forthcoming.

Degryse, H., Ongena, S. (2007). The impact of competition on bank orientation, Journal of Financial Intermediation 16: 399-424.

Delis, M., Hasan, I., Kazakis, P. (2014). Bank regulations and income inequality: Empirical evidence. Review of Finance 18: 1811-1846.

EU Federation - EUF (2015). White paper on factoring and commercial finance, https://euf.eu.com

Fernández de Guevara, J., Maudos, J., Pérez, F., 2005. Market power in European banks. Journal of Financial Services Research 27: 109-137.

Fiordelisi, F., Mare, D. (2014). Competition and Financial Stability in European Cooperative Banks. Journal of International Money and Finance 45: 1-16.

Fiordelisi, F., Mare, D., Molyneux, P. (2018). State-Aid, Stability and Competition in European Banking. MPRA Paper 67473, University Library of Munich, Germany.

Fiordelisi, F., Molyneux, P. (2004). Efficiency in the factoring industry. Applied Economics 90: $947-959$.

Forssbæck, J., Shehzad, C.T. (2015). The Conditional Effects of Market Power on Bank Risk Cross - Country Evidence. Review of Finance 10(5): 1997-2038.

Fu, X.M., Lin, Y.R., Molyneux, P. (2014). Bank competition and financial stability in Asia Pacific. Journal of Banking \& Finance 38: 64-77.

Goddard, J., Wilson, J.O.S. (2009). Competition in banking: A disequilibrium approach. Journal of Banking \& Finance 33: 2282-2292. 
Hakenes, H., Schnabel, I. (2010). Banks Without Parachutes: Competitive Effects of Government Bail-Out Policies. Journal of Financial Stability 6: 156-168.

Hansen, L.P. (1982). Large sample properties of Generalized Method of Moments estimators. Econometrica 50: 1029-1054.

Hayakawa, K. (2009). First Di erence or Forward Orthogonal Deviation - Which Transformation Should be Used in Dynamic Panel Data Models?: A Simulation Study. Economics Bulletin 29(3): 2008-2017.

Hayakawa, K (2016). Improved GMM estimation of panel VAR models Computational Statistics and Data Analysis 100: 240-264.

Head, A., Lloyd-Ellis, H., Sun, S. (2014). Search, Liquidity, and the Dynamics of House Prices and Construction. American Economic Review 104(4): 1172-1210.

Hesse, H., Čihák, M. (2007). Cooperative banks and financial stability. International Monetary Fund, Working Paper 07/02.

Keeley, M.C. (1990). Deposit insurance, risk, and market power in banking. The American Economic Review 80(5): 1183-1200.

Koetter, M., Kolari, J.W., Spierdijk, L. (2012). Enjoying the quiet life under deregulation? Evidence from adjusted Lerner indices for US banks. Review of Economics and Statistics 94: 462-480.

Laeven, L., Levine, R. (2009). Bank governance, regulation, and risk taking. Journal of Financial Economics 93: 259-275.

Lepetit, L., Strobel, F. (2013). Bank insolvency risk and time-varying Z-score measures. Journal of International Financial Markets, Institutions and Money 25: 73-87.

Liu, H., Molyneux, P. and Wilson, J.O.S. (2013). Competition and stability in European banking: a regional analysis. Manchester School 81, 176-201

Liu, H., Molyneux, P., Wilson J.O.S. (2013). Competition in banking: measurement and interpretation. Chapter 8 In: Bell, A.R., Brooks, C., Prokopczuk, M., (eds.) Handbook of Research Methods and Applications in Empirical Finance. Edward Elgar, 197-215.

Liu, H., Wilson, J.O.S. (2013). Competition and risk in Japanese banking. European Journal of Finance 19(1): 1-18.

Love, I., Zicchino, L. (2006). Financial development and dynamic investment behavior: Evidence from panel VAR. The Quarterly Review of Economics and Finance 46(2): 190-210.

Martinez-Miera, D., Repullo, R. (2010). Does competition reduce the risk of bank failure? Review of Financial Studies 23: 3638-3664.

Radic, N., Girardone, C. Fiordelisi, F. (2012). Efficiency and Risk-Taking in Pre-Crisis Investment Banks. Journal of Financial Service Research 41(1-2): 81-101.

Schaeck, K., Cihak, M. (2014). Competition, efficiency, and stability in banking. Financial Management 43: 215-241.

Schaeck, K., Cihak, M., Wolfe, S. (2009). Are competitive banking systems more stable? Journal of Money, Credit \& Banking 41(4): 711-734. 
Soedarmono, W., Tarazi, A. (2015). Competition, financial intermediation, and riskiness of banks: evidence from the Asia-Pacific region. Emerging Markets Finance and Trade 52(4): 951974.

Stein, J.C., Usher, S.E., La Gattuta, D., Youngen, J. (2001). A comparables approach to measuring cashflow-at-risk for non-financial firms. Journal of Applied Corporate Finance 13(4): 100109.

Turk-Ariss, R. (2010). On the implications of market power in banking: Evidence from developing countries. Journal of Banking and Finance 34: 765-775.

Wilson, John O.S. Casu, B., Girardone, G, Molyneux, M. (2010). Emerging themes in banking: Recent literature and directions for future research, The British Accounting Review 42: 153169. 
Table 1 - The GDP penetration of factoring and specialized credit in Italy 2011-2016

\begin{tabular}{|ccccccc|}
\hline & $\mathbf{2 0 1 1}$ & $\mathbf{2 0 1 2}$ & $\mathbf{2 0 1 3}$ & $\mathbf{2 0 1 4}$ & $\mathbf{2 0 1 5}$ & $\mathbf{2 0 1 6}$ \\
\hline Factoring/ GDP & $10,46 \%$ & $11,18 \%$ & $11,13 \%$ & $11,51 \%$ & $11,86 \%$ & $12,87 \%$ \\
$\begin{array}{c}\text { Specialized Credit } \\
\text { factoring, leasing } \\
\text { and household credit } \\
\text { sector)/ GDP }\end{array}$ & $16,8 \%$ & $15,8 \%$ & $15,3 \%$ & $15,4 \%$ & $17,0 \%$ & $18,8 \%$ \\
\hline
\end{tabular}

Source: Assifact e Istat 


\section{Table 2 - Sample composition}

This table reports the number of firm-observations in our sample for each year in Italy between 2008 and 2015 by distinguishing between the factoring and banking industry.

\begin{tabular}{lccccccccc}
\hline Type of Institutions & $\mathbf{2 0 0 8}$ & $\mathbf{2 0 0 9}$ & $\mathbf{2 0 1 0}$ & $\mathbf{2 0 1 1}$ & $\mathbf{2 0 1 2}$ & $\mathbf{2 0 1 3}$ & $\mathbf{2 0 1 4}$ & $\mathbf{2 0 1 5}$ & Total \\
\hline Commercial Banks & 53 & 55 & 62 & 68 & 68 & 71 & 71 & 67 & 515 \\
Factoring Firms & 33 & 30 & 28 & 23 & 22 & 21 & 18 & 17 & 192 \\
\hline Total & 86 & 85 & 90 & 91 & 90 & 92 & 89 & 84 & $\mathbf{7 0 7}$ \\
\hline
\end{tabular}




\section{Table 3 - Variables description}

This table reports the description of the variables used in the empirical analysis. All data for commercial banks has been collected from Fitch-IBCA BankScope (BSC), while data for factoring firms has been kindly provided by OSSFIN database.

\begin{tabular}{|c|c|c|}
\hline Variable & Symbol & DESCRIPTION \\
\hline Return on assets & ROA & Net Income/Total Assets \\
\hline Return on equity & ROE & Net Income/Equity \\
\hline Capitalization & ETA & Equity/Total Assets \\
\hline Z-score & Z-score & $\mu(\mathrm{ROA})+\mathrm{ETA} / \sigma(\mathrm{ROA})$ \\
\hline Capital At Risk & CAR & Earning at Risk/ROE \\
\hline Size & Size & Logarithm of Total Assets \\
\hline Market Share & MS & $\sum_{i=1}^{N} T A_{i} / T A_{N}$ \\
\hline $\begin{array}{l}\text { Herfindahl- } \\
\text { Hirschman Index }\end{array}$ & HHI & $\sum_{i=1}^{N} M S_{i}^{2}$ for all the banks and factoring firms. \\
\hline Lerner Index & Lerner Index & $(\mathrm{P}-\mathrm{MC}) / \mathrm{P}$. See below for further details. \\
\hline Firm output & $\mathrm{Y}$ & Logarithm of total Earning assets \\
\hline Price of Labor & P_Lab & Personnel Expenses/ Total Assets \\
\hline Price of Fixed Assets & P_FA & Other Operating Expenses/Fixed Assets \\
\hline $\begin{array}{l}\text { Price of Debt for } \\
\text { Commercial Banks }\end{array}$ & P_Debt_Banks & $\begin{array}{l}\text { Total Interest Expenses/(Total Deposits + Money Market }+ \\
\text { Short-Term Funding) }\end{array}$ \\
\hline $\begin{array}{l}\text { Price of Debt for } \\
\text { Factoring Firms }\end{array}$ & P_Debt_Factoring & Total Interest Expenses/ Total Debts \\
\hline Total Costs & $\mathrm{TC}$ & $\begin{array}{l}\text { Personnel Expenses }+ \text { Other Operating Expenses }+ \text { Total } \\
\text { Interest Expenses }\end{array}$ \\
\hline Marginal Cost & $\mathrm{MC}$ & $\begin{array}{l}\text { The marginal cost is calculated by using the translog function, } \\
\text { as defined in the equations } 2 \text { and } 3\end{array}$ \\
\hline $\begin{array}{l}\text { Price for commercial } \\
\text { banks }\end{array}$ & $\mathrm{P}_{-}$Banks & $\begin{array}{l}\text { (Total Non-Interest Operating Income }+ \text { Interest Income on } \\
\text { Loans }+ \text { Other Interest Income)/Total Earning Assets }\end{array}$ \\
\hline $\begin{array}{l}\text { Price for Factoring } \\
\text { Firms }\end{array}$ & P_Factoring & Total Interest Income on Earning assets/ Total Earning Assets \\
\hline
\end{tabular}




\section{Table 4 - Summary statistics}

This table reports the descriptive statistics used in the empirical analysis.

\begin{tabular}{lrrrr}
\hline VARIABLES & Mean & Std. Dev. & $\mathbf{5 \%}$ & $\mathbf{9 5 \%}$ \\
\hline Equity $(*)$ & $48,059.224$ & $158,627.942$ & 19.149 & $306,670.000$ \\
Profit before Taxes $\left(^{*}\right)$ & $6,145.805$ & $25,245.219$ & -418.000 & $50,718.000$ \\
ROA & -0.054 & 1.771 & -1.993 & 1.183 \\
ETA & 0.116 & 0.112 & 0.033 & 0.349 \\
Z-score $(\ln )$ & 3.259 & 7.414 & -0.210 & 15.590 \\
ROE & 0.020 & 0.204 & -0.225 & 0.228 \\
CAR & 11.815 & 1.902 & 9.020 & 14.975 \\
SIZE & 9.617 & 3.143 & 4.529 & 15.435 \\
MS & 0.022 & 0.060 & 0.001 & 0.143 \\
HHI & 0.214 & 0.053 & 0.120 & 0.302 \\
\hline P_Lab & 0.020 & 0.016 & 0.003 & 0.052 \\
P_FA & 17.820 & 50.517 & 0.322 & 92.143 \\
P_Debt & 0.013 & 0.014 & 0.003 & 0.030 \\
Total Costs(ln) & 6.165 & 2.983 & 1.620 & 11.231 \\
Y & 9.881 & 3.606 & 4.389 & 15.913 \\
MC & 0.037 & 0.152 & 0.007 & 0.051 \\
P & 0.069 & 0.228 & 0.018 & 0.101 \\
Lerner Index-Commercial Banks & 0.488 & 0.214 & 0.149 & 0.684 \\
Lerner Index-Factoring Firms & 0.410 & 0.244 & 0.011 & 0.679 \\
\hline
\end{tabular}

Note: $(*)$ Values in EUR thousands. 


\section{Table 5. Comparing competition levels in factoring and leasing industry}

This table shows a two-sample t test with equal variances for the Lerner index by comparing banks (group 1) and factoring firms (group 2) in the Italian credit industry between 2008 and 2015. The null hypothesis states that there is no difference between the two group means. The symbols * and ** indicate significance at $5 \%$ and $1 \%$ levels, respectively.

\begin{tabular}{ccccccc}
\hline Group & No. Observations & Mean & Std. Err. & Std. Dev. & [95\% Conf. Interval] \\
\hline $\begin{array}{c}(1) \\
\text { Banks }\end{array}$ & 515 & 0.488 & 0.009 & 0.214 & 0.469 & 0.507 \\
$\begin{array}{c}(2) \\
\text { Factoring }\end{array}$ & 192 & 0.410 & 0.017 & 0.244 & 0.376 & 0.445 \\
Mean & 707 & 0.467 & 0.008 & 0.225 & 0.450 & 0.484 \\
\hline $\begin{array}{c}(1-2) \\
\text { Difference }\end{array}$ & $0.077^{* * *}$ & 0.019 & & 0.047 & 0.121 \\
\hline
\end{tabular}

Note: $* * * \mathrm{p}<.01$ 


\section{Table 6 - Results}

This table reports the results of the regression where the dependent variable refers to firms' stability measures, respectively the log of the Z-score and the log of the Capital At Risk (CAR). The independent variables are: i) a dummy variable capturing the type of credit-institution (i.e. 1 for factoring firms, 0 for commercial banks), the Lerner index, the firm market share. We also control for firms asset size calculated as the logarithm of total assets. We include bank fixed effects $\left(A_{\mathrm{i}}\right)$ and year*factoring fixed effects $\left(B_{\mathrm{y}^{*} \mathrm{f}}\right)$. Robust standard errors in parentheses are clustered at the bank level. $*$ and $* *$ indicate significance at the $5 \%$ and $1 \%$ levels, respectively. All variables are defined in Table 3 .

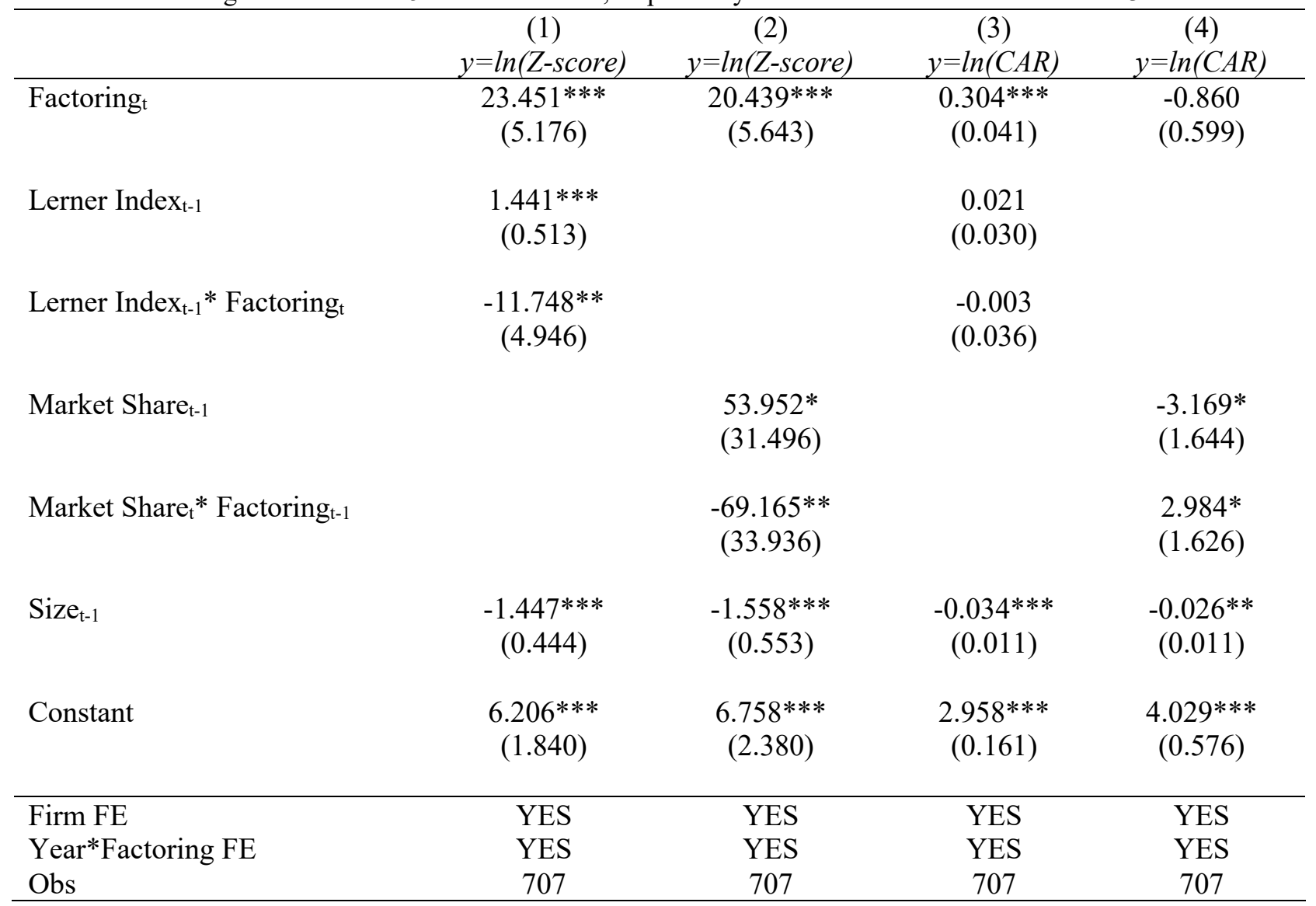

Note: Robust Standard Errors. ${ }^{*} \mathrm{p}<.1,{ }^{* *} \mathrm{p}<.05,{ }^{* * *} \mathrm{p}<.01$ 


\section{Table 7 - Forecast-Error Variance Decomposition}

This table reports the forecast-error variance decomposition (FEVD) based on a Cholesky decomposition of the residual covariance matrix of the underlying panel VAR model and again using 1,000 Monte Carlo simulations. It shows the percentage of variation in one variable explained by the 'shock' (i.e. change) to another variable over three periods ahead. There are two models. In the first model, there are Z-score and Lerner Index, while in the second one there are CAR and Lerner Index. The models are presented for both the factoring and banking industry. All variables are defined in Table 3.

\begin{tabular}{|c|c|c|c|c|c|}
\hline $\begin{array}{l}\text { Response variable and } \\
\text { forecast horizon }\end{array}$ & $\begin{array}{l}\text { Factorin } \\
\text { g Firms }\end{array}$ & $\begin{array}{l}\text { Commerci } \\
\text { al Banks }\end{array}$ & $\begin{array}{l}\text { Response variable and } \\
\text { forecast horizon }\end{array}$ & $\begin{array}{l}\text { Factorin } \\
\text { g Firms }\end{array}$ & $\begin{array}{l}\text { Commerci } \\
\text { al Banks }\end{array}$ \\
\hline & \multicolumn{2}{|c|}{$\begin{array}{l}\text { Impulse Variable: } \\
\text { Lerner Index }\end{array}$} & & \multicolumn{2}{|c|}{$\begin{array}{l}\text { Impulse Variable: Z- } \\
\text { score }\end{array}$} \\
\hline \multirow[t]{5}{*}{ Z-score } & & & Lerner Index & & \\
\hline & 0.000 & 0.000 & c & 0.000 & 0.000 \\
\hline & 0.000 & 0.000 & 1 & 0.018 & 0.034 \\
\hline & 0.028 & 0.004 & 2 & 0.165 & 0.100 \\
\hline & 0.027 & 0.005 & 3 & 0.163 & 0.110 \\
\hline \multirow[t]{5}{*}{ CAR } & & & Lerner Index & \multicolumn{2}{|c|}{ Impulse Variable: CAR } \\
\hline & 0.000 & 0.000 & c & 0.000 & 0.000 \\
\hline & 0.000 & 0.000 & 1 & 0.048 & 0.000 \\
\hline & 0.115 & 0.001 & 2 & 0.397 & 0.0001 \\
\hline & 0.207 & 0.002 & 3 & 0.519 & 0.0002 \\
\hline
\end{tabular}




\section{Figure 1 - The evolution of competition indicators in the Factoring industry}

This figure reports the evolution of competition and stability indicators in the factoring industry over time. Specifically, we report the Herfindahl-Hirschman Index for factoring companies (panel A: top left), measured with the outstanding value of trade credits at the end of the year (HHI-ANT) and the overall value of all trade credits in the year (HHI-TR). In the panel B (top-left), we report the Lerner index for factoring companies. In the Panel C (down-left) and D (Downright), we report the HHI (calculated based on total assets) and the Lerner indices for banks, respectively. In all graphs, years: $1, \ldots, 8$ correspond to years: $2008-2015$.

\section{$\underline{\text { Panel A }}$}

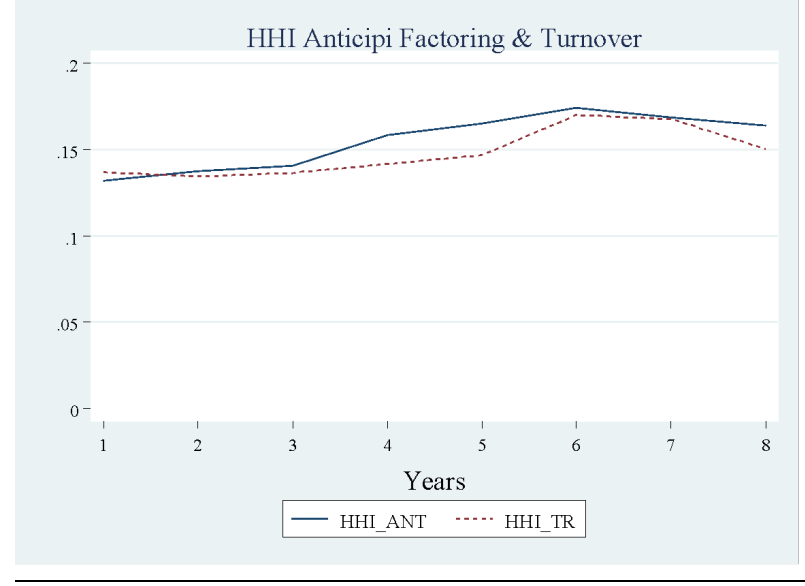

$\underline{\text { Panel C }}$

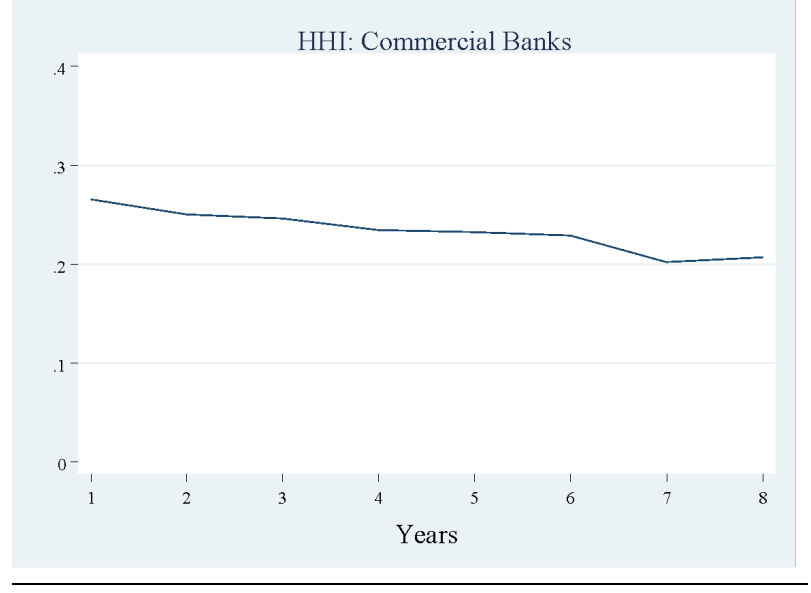

\section{$\underline{\text { Panel B }}$}

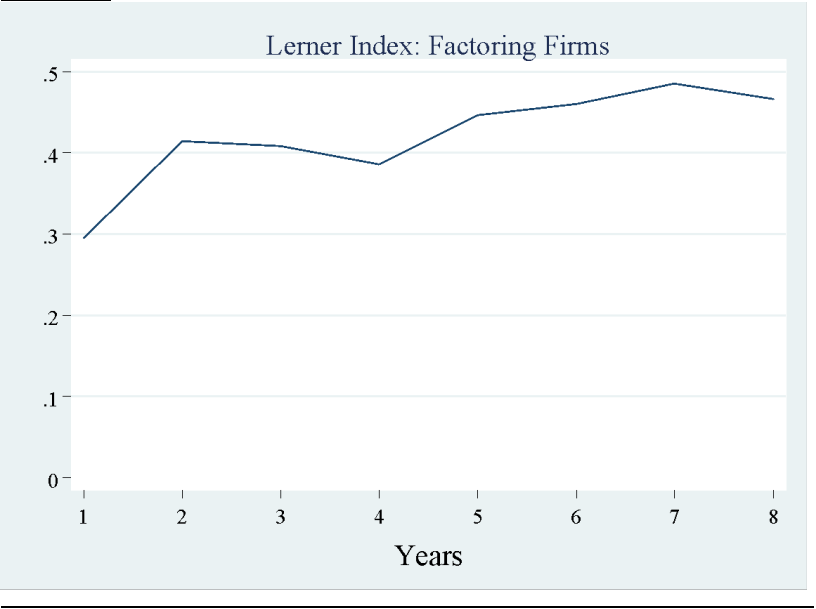

$\underline{\text { Panel D }}$

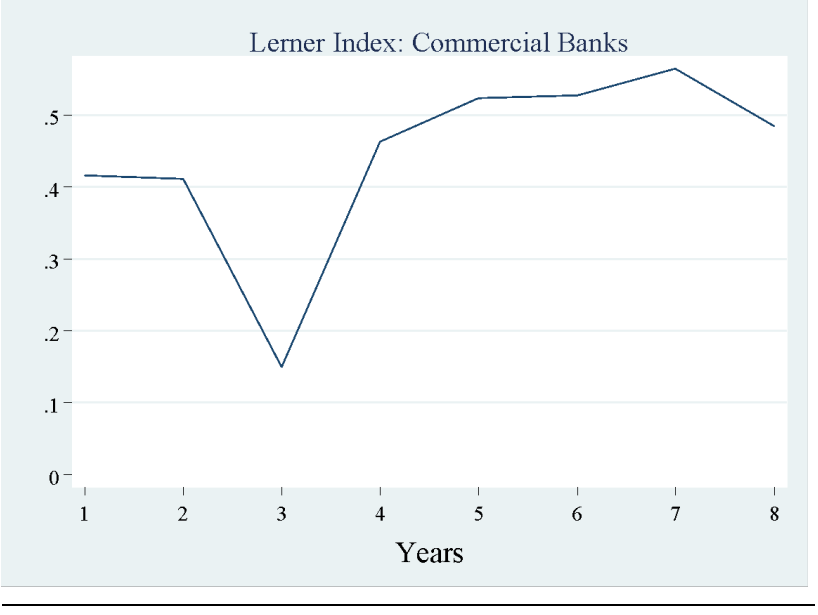




\section{Figure 2 - Impulse Response Functions for Factoring firms}

This figure illustrates the impulse response functions (IRFs) of each endogenous variable with respect to one standard deviation shock in other variables for the factoring industry. We employ 1,000 Monte Carlo simulations to get bootstrapped confidence intervals for the impulse response functions. We also subtract from each variable in the model its cross-sectional mean before estimation to remove time fixed effects. All variables are defined in Table 3.

\section{$\underline{\text { Panel A -Impulse: Lerner Index }}$}

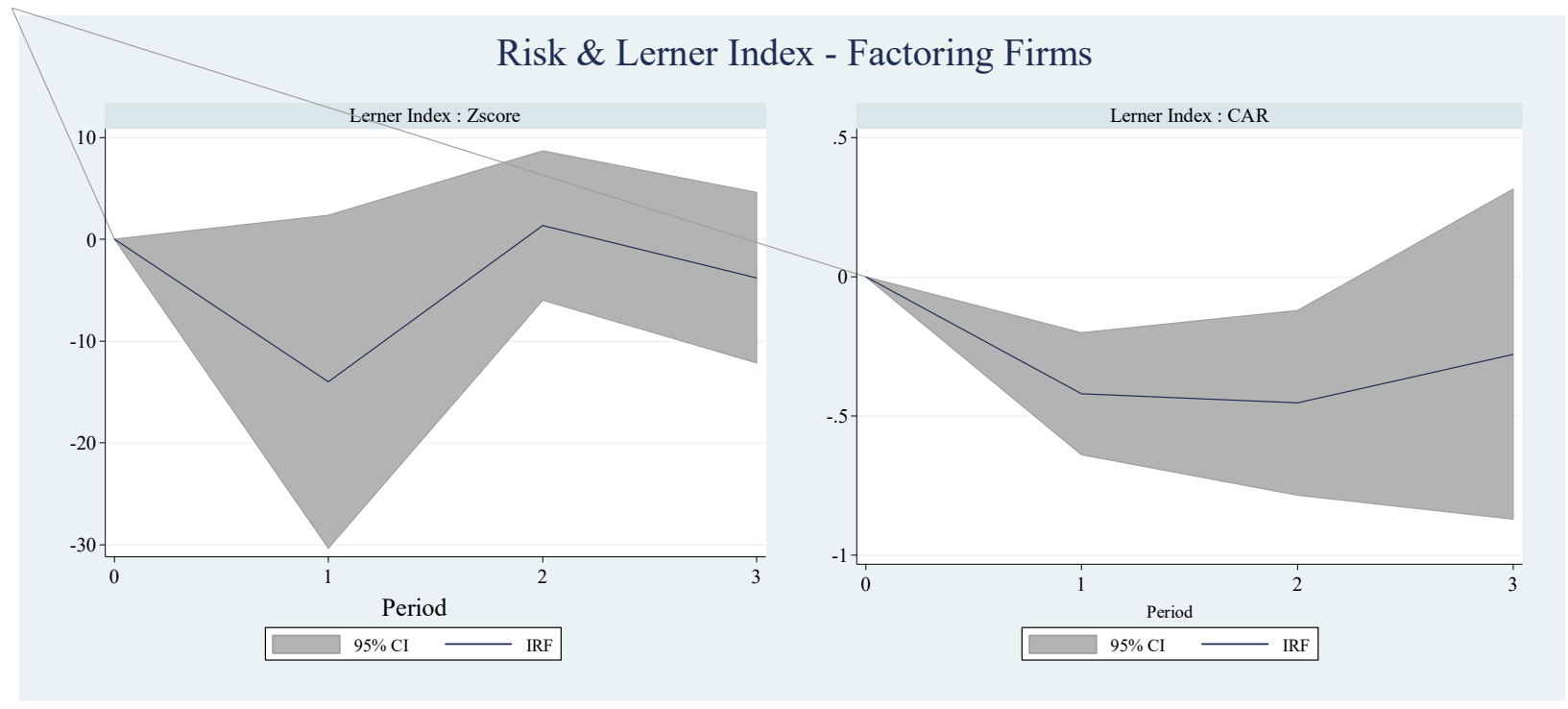

Note Figure (a) Test of overidentifying restriction: Hansen's J chi2(12) $=23.507(\mathrm{p}=0.101)$; Figure (b) Hansen's J chi2(12) $=$ $12.939(\mathrm{p}=0.114)$. Impulse: Lerner Index. Impulse Response Functions (IRF). 95\% Confidence Interval (CI) generated by MonteCarlo with 1000 reps

\section{$\underline{\text { Panel B -Impulse: Z-score and CAR }}$}
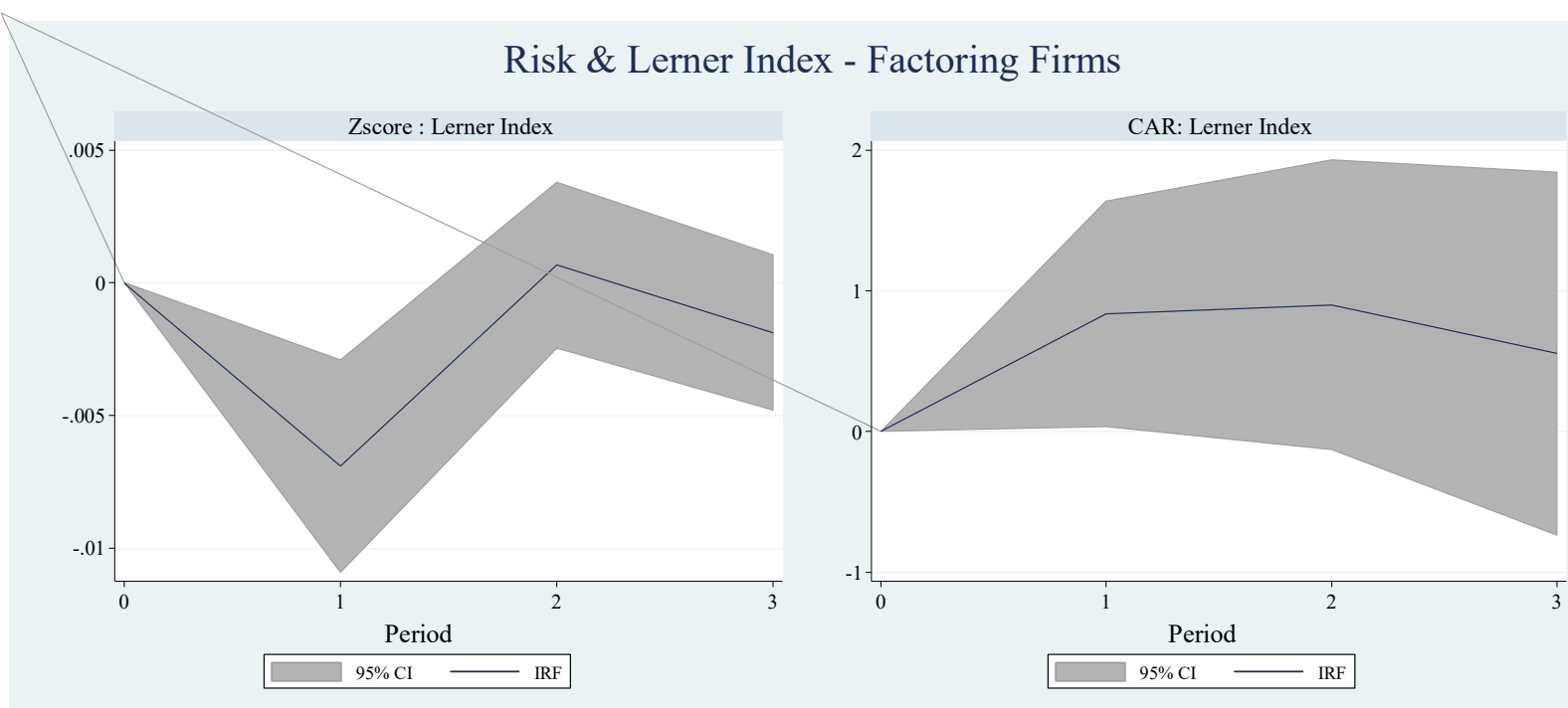

Note Figure (c) Test of overidentifying restriction: Hansen's J chi2(12) $=23.507(p=0.101)$; Figure $(d)$ Hansen's J chi2(12) = $12.939(\mathrm{p}=0.114)$. Impulse: Z-Score and CAR. Impulse Response Functions (IRF). 95\% Confidence Interval (CI) generated by Monte-Carlo with 1000 reps 


\section{Figure 3 - Impulse Response Functions for Commercial Banks}

This figure illustrates the impulse response functions (IRFs) of each endogenous variable with respect to one standard deviation shock in other variables for the banking industry. We employ 1,000 Monte Carlo simulations to get bootstrapped confidence intervals for the impulse response functions. We also subtract from each variable in the model its cross-sectional mean before estimation to remove time fixed effects. All variables are defined in Table 3.

\section{Panel A -Impulse: Lerner Index}

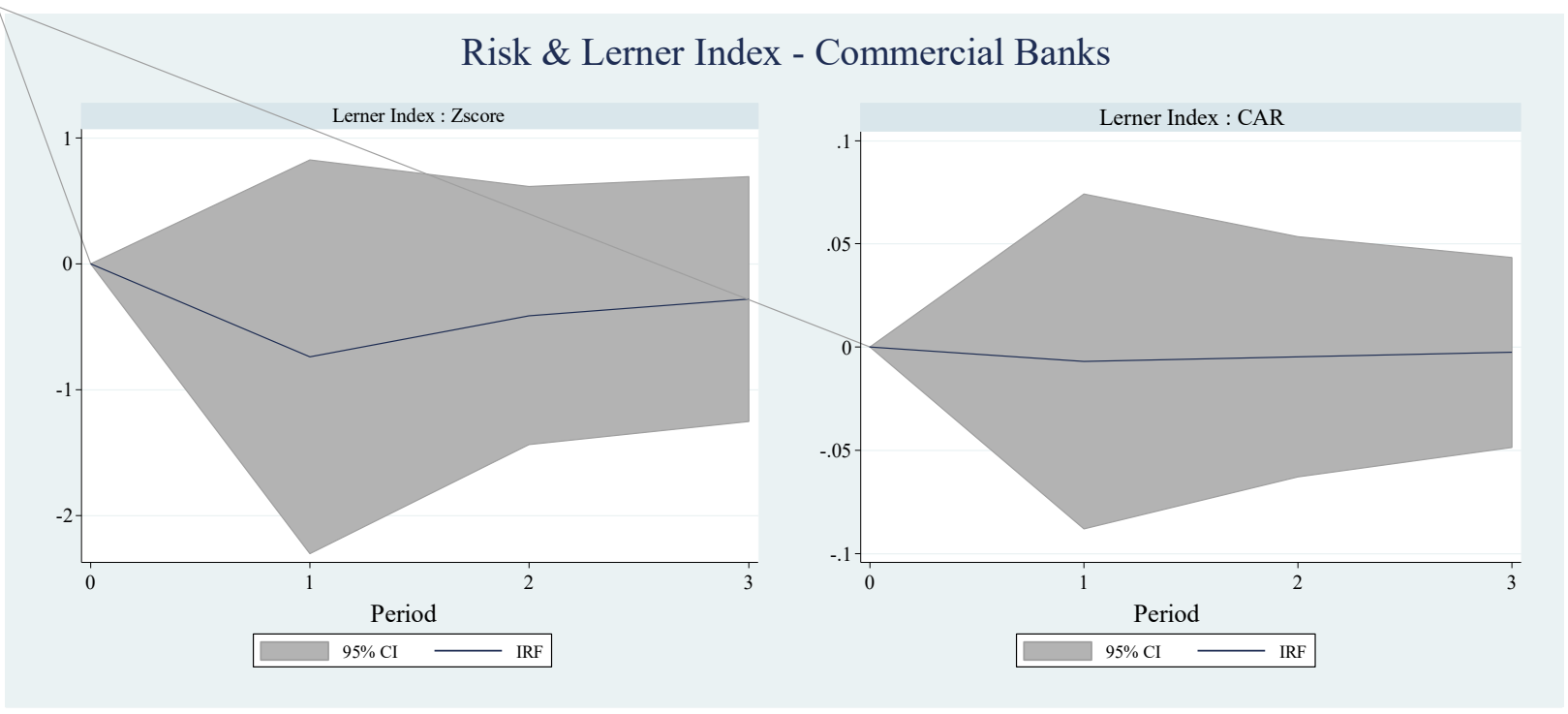

Note: Figure (a) Hansen's J chi2(8) = $8.673(\mathrm{p}=0.371)$; Figure (b) Hansen's J chi2 $(8)=8.699(\mathrm{p}=0.728)$. Impulse: Lerner Index. Impulse Response Functions (IRF). 95\% Confidence Interval (CI) generated by Monte-Carlo with 1000 reps

\section{Panel B-Impulse: Z-score and CAR}

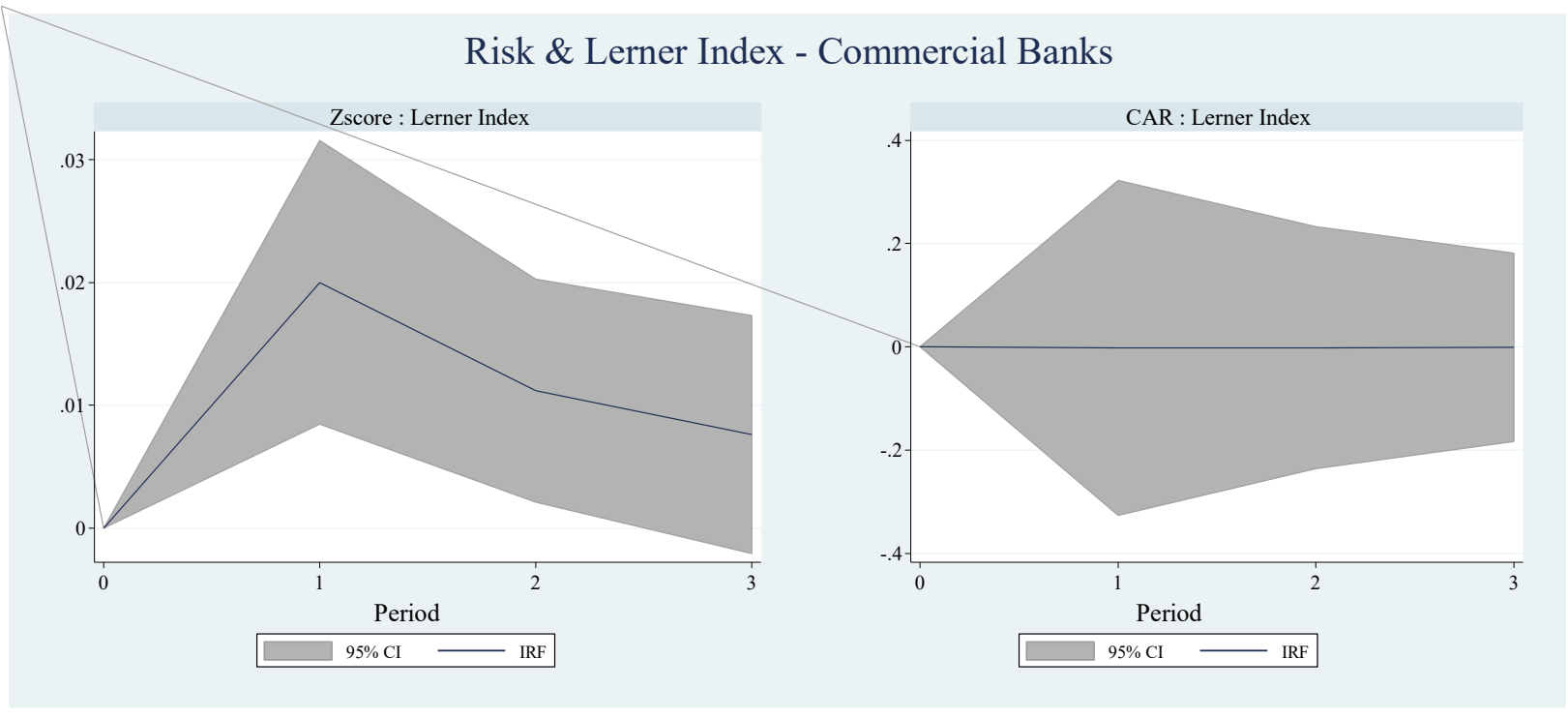

Note: Figure (c) Hansen's J chi2(8) = $8.673(\mathrm{p}=0.371)$; Figure $(\mathrm{d})$ Hansen's J chi2(8) $=8.699(\mathrm{p}=0.728)$. Impulse: Z-score and CAR. Impulse Response Functions (IRF). 95\% Confidence Interval (CI) generated by Monte-Carlo with 1000 reps. 


\section{Appendix A. List of Factoring Firms and Commercial Banks}

\begin{tabular}{|c|c|}
\hline $\begin{array}{l}\text { Commercial Banks } \\
\text { BancApulia }\end{array}$ & $\begin{array}{l}\text { Factoring Firms } \\
\mathrm{Abf}\end{array}$ \\
\hline BancApulia & Abf \\
\hline Banca AGCI & Aosta Factor \\
\hline Banca Capasso Antonio & B. Farmafactoring \\
\hline Banca Carige Italia & Banca Ifis \\
\hline Banca Carige & BCC Factoring \\
\hline Banca Carime & Centro Factoring \\
\hline Banca Del Vomano & Coface Factoring \\
\hline Banca Di Saturnia E Costa D'Argento & Comfactor \\
\hline Banca Emilveneta & Credem Factor \\
\hline Banca Federico del Vecchio & Credit Agricole Comm. Finance \\
\hline Banca Finnat Euramerica & Emil-Ro Factor \\
\hline Banca Generali SpA & Enel.Factor \\
\hline Banca ITB & Eurofactor \\
\hline Banca Ifis & Factorcoop \\
\hline Banca Interprovinciale & Factorit \\
\hline Banca Mediolanum & Fercredit \\
\hline Banca Monte Parma & Fidis \\
\hline Banca Monte dei Paschi di Siena & Fortis Comm. Fin. \\
\hline Banca Nazionale del Lavoro SpA-BNL & Ge Capital Fin. \\
\hline Banca Nuova & General Finance \\
\hline Banca Passadore \& C. & IBM IT SF \\
\hline Banca Popolare Commercio e Industria & Ifitalia \\
\hline Banca Popolare Del Mediterraneo & Mediofactoring \\
\hline Banca Popolare FriulAdria & Meliorfactoring \\
\hline Banca Popolare di Bergamo & MPS L\&F \\
\hline Banca Popolare di Mantova & Ries Factoring \\
\hline Banca Popolare di Spoleto & Serfactoring \\
\hline Banca Profilo & SG Factoring \\
\hline Banca Promos & Tex Factor \\
\hline Banca Regionale Europea & Ubi Factor \\
\hline Banca Santa Giulia & Unicredit Factoring \\
\hline \multicolumn{2}{|l|}{ Banca Sella } \\
\hline \multicolumn{2}{|l|}{ Banca Sistema } \\
\hline \multicolumn{2}{|l|}{ Banca Stabiese } \\
\hline \multicolumn{2}{|l|}{ Banca Sviluppo Economico } \\
\hline \multicolumn{2}{|l|}{ Banca del Fucino } \\
\hline \multirow{2}{*}{\multicolumn{2}{|c|}{$\begin{array}{l}\text { Banca del Lavoro e del Piccolo } \\
\text { Risparmio }\end{array}$}} \\
\hline & \\
\hline Banca del Monte di Lucca & \\
\hline Banca del Piemont & \\
\hline
\end{tabular}


Banca del Sud

Banca della Provincia di Macerata

Banca di Imola

Banca di Sassari

Banca di Sconto e Conti Correnti di S.

Banca di Trento e Bolzano

Banca di Valle Camonica

Banco delle Tre Venezie

Banco di Brescia San Paolo Cab

Banco di Credito P. Azzoaglio

Banco di Desio e della Brianza

Banco di Lucca E Del Tirreno

Banco di Napoli

Banco di Sardegna

BancoPosta-Poste Italiane

Cassa Centrale Banca Credito Cooperat.

Cassa di Risparmio di Cesena

CheBanca

Compass

Credito Emiliano

Credito Siciliano

Credito di Romagna

Dea Capital

Deutsche Bank

Dobank

Extrabanca

Farbanca

Findomestic Banca

FinecoBank Banca FinEco

IBL Istituto Bancario del Lavoro

Igd

Imprebanca

Intesa Sanpaolo

Italmobiliare

$\mathrm{M} \& \mathrm{C}$

Mediobanca

Meridie

Nuova Banca Dell'etruria E Del Lazio

Nuova Banca delle Marche

Nuova Cassa Di Risparmio Di Chieti

UBS (Italy)

UniCredit

Unipol Banca 
Credit Suisse (Italy) 


\section{Table A: Lerner Index and Risk: Full Sample}

This table reports the results of the regression where the dependent variable refers to firms' stability measures, respectively the log of the Z-score and the log of the Capital At Risk (CAR). The independent variables are: i) a dummy variable capturing the type of credit-institution (i.e. 1 for factoring firms, 0 for commercial banks), the Lerner index, the firm market share. We also control for firms asset size calculated as the logarithm of total assets. We include bank fixed effects $\left(A_{\mathrm{i}}\right)$ and year*factoring fixed effects $\left(B_{\mathrm{y}^{*}}\right)$. Robust standard errors in parentheses are clustered at the bank level. $*$ and $* *$ indicate significance at the $5 \%$ and $1 \%$ levels, respectively. All variables are defined in Table 3 .

\begin{tabular}{|c|c|c|}
\hline & $\begin{array}{c}(1) \\
y=\ln (Z-\text { score })\end{array}$ & $\begin{array}{c}(2) \\
y=\ln (C A R)\end{array}$ \\
\hline Factoring $_{t}$ & $\begin{array}{c}25.791 * * * \\
(5.273)\end{array}$ & $\begin{array}{c}0.302 * * * \\
(0.043)\end{array}$ \\
\hline Lerner Index $\mathrm{x}_{\mathrm{t}-1}$ & $\begin{array}{c}1.307 * * * \\
(0.475)\end{array}$ & $\begin{array}{c}0.021 \\
(0.030)\end{array}$ \\
\hline Lerner Index $_{\mathrm{t}-1} *$ Factoring $_{\mathrm{t}}$ & $\begin{array}{c}-15.639 * * * \\
(5.433)\end{array}$ & $\begin{array}{l}-0.004 \\
(0.037)\end{array}$ \\
\hline Size $_{t-1}$ & $\begin{array}{c}-1.249 * * * \\
(0.416)\end{array}$ & $\begin{array}{c}-0.034 * * * \\
(0.012)\end{array}$ \\
\hline Constant & $\begin{array}{c}5.390 * * * \\
(1.720)\end{array}$ & $\begin{array}{c}2.960 * * * \\
(0.163)\end{array}$ \\
\hline $\begin{array}{l}\text { Firm FE } \\
\text { Year*Factoring FE } \\
\text { Obs }\end{array}$ & $\begin{array}{l}\text { YES } \\
\text { YES } \\
707\end{array}$ & $\begin{array}{l}\text { YES } \\
\text { YES } \\
707\end{array}$ \\
\hline
\end{tabular}

Note: Robust Standard Errors. ${ }^{*} \mathrm{p}<.1,{ }^{* *} \mathrm{p}<.05,{ }^{* * *} \mathrm{p}<.01$ 